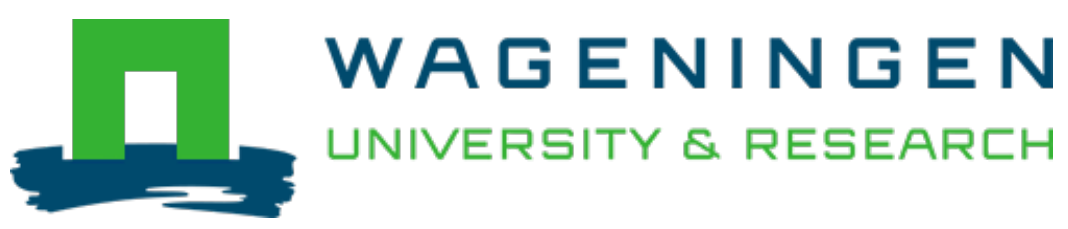

\author{
Genetic structure in populations of an ancient woodland sedge, carex sylvatica \\ Hudson, at a regional and local scale. \\ Plant Biology \\ Arens, P.F.P.; Bijlsma, R.J.; Westende, W.P.C.; Os, B.; Smulders, M.J.M. et al \\ https://doi.org/10.1055/s-2005-865644
}

This article is made publicly available in the institutional repository of Wageningen University and Research, under the terms of article $25 \mathrm{fa}$ of the Dutch Copyright Act, also known as the Amendment Taverne. This has been done with explicit consent by the author.

Article 25 fa states that the author of a short scientific work funded either wholly or partially by Dutch public funds is entitled to make that work publicly available for no consideration following a reasonable period of time after the work was first published, provided that clear reference is made to the source of the first publication of the work.

This publication is distributed under The Association of Universities in the Netherlands (VSNU) 'Article $25 \mathrm{fa}$ implementation' project. In this project research outputs of researchers employed by Dutch Universities that comply with the legal requirements of Article $25 \mathrm{fa}$ of the Dutch Copyright Act are distributed online and free of cost or other barriers in institutional repositories. Research outputs are distributed six months after their first online publication in the original published version and with proper attribution to the source of the original publication.

You are permitted to download and use the publication for personal purposes. All rights remain with the author(s) and / or copyright owner(s) of this work. Any use of the publication or parts of it other than authorised under article $25 \mathrm{fa}$ of the Dutch Copyright act is prohibited. Wageningen University \& Research and the author(s) of this publication shall not be held responsible or liable for any damages resulting from your (re)use of this publication.

For questions regarding the public availability of this article please contact openscience.library@,wur.nl 


\title{
Genetic Structure in Populations of an Ancient Woodland Sedge, Carex sylvatica Hudson, at a Regional and Local Scale
}

\author{
P. Arens', R.-J. Bijlsma², W. van't Westende'1, B. van Os², M. J. M. Smulders', and B. Vosman ${ }^{1}$ \\ ${ }^{1}$ Department of Biodiversity and Breeding, Plant Research International, Wageningen UR, P.O. Box 16, 6700 AA Wageningen, The Netherlands \\ ${ }^{2}$ Centre for Ecosystem Studies, Alterra, Wageningen UR, P.O. Box 47, 6700 AA Wageningen, The Netherlands
}

Received: December 10, 2004; Accepted: April 11, 2005

\begin{abstract}
Wood sedge (Carex sylvatica) is a well-known ancient woodland species with a long-term persistent seed bank and a caespitose growth habit. All thirteen isolated Carex sylvatica populations in the Dutch Rhine floodplain (including the river branches Waal and IJssel) were mapped in detail and analysed for genetic variation at a large number of AFLP loci and one microsatellite locus. Across all populations, only $40 \%$ of the sampled individuals $(n=216)$ represented a unique genotype. A high number of the studied patches (spatial clusters of tussocks, 2$10 \mathrm{~m}$ in diameter) within populations contained only one or a few genotypes. Identical plants (tussocks) were also found 20 $500 \mathrm{~m}$ apart and in one case even $1000 \mathrm{~m}$ apart. Observed heterozygosity levels $\left(\mathrm{H}_{\mathrm{O}}=\mathbf{0 . 0 2 9}\right)$ were low, indicating low levels of gene flow, which is in agreement with the selfing nature of other caespitose sedges. Although the number of genotypes in populations is low, these genotypes are genetically very distinct and variation within populations accounted for $55 \%$ of the total variation. The absence of a correlation between genetic and geographic distances among populations, and the scattered distribution of genotypes among patches within woodlands, support our hypothesis of rare establishments and subsequent local dispersal within woodlands in this forest floor species, which may benefit from and partly depend on human land use and forest management activities.
\end{abstract}

Key words: AFLP, genetic diversity, molecular markers, Carex sylvatica, dispersal mode, disturbance, management.

\section{Introduction}

The concept of ancient woodland has been advanced by several British authors, especially Rackham $(1976,1980)$. Ancient woods occupy sites that have been wooded continuously at least for several centuries, and many of them are remnants of medieval woodlands. Regional investigations of the history of woodlands have revealed that many woodland herbs were almost completely restricted to ancient woods and may be regarded as indicators of ancient woodland (e.g., Wulf, 1997).

Plant Biol. 7 (2005): 387-396

(C) Georg Thieme Verlag KG Stuttgart · New York

DOI $10.1055 / \mathrm{s}-2005-865644$

ISSN 1435-8603
An important characteristic of ancient woodland plant species is their poor ability to colonise secondary woods, attributed to limited dispersal capacity, low seed production, or recruitment problems (Hermy et al., 1999). Although the conservation value of ancient woods is now widely recognised (e.g., Peterken, 1994), certain aspects concerning the concept of ancient woodland indicators have been challenged (Bonn and Poschlod, 1998; Nordén and Appelqvist, 2001). The most important objection is that the dispersal capacity of woodland species generally appears to be underestimated. Based on seed characteristics, many woodland plant species are supposed to be dispersed by ants or have no obvious dispersal mechanism at all (Hermy et al., 1999). However, it is not unusual to find small and apparently young populations of these kinds of species far from ancient woods, as indicated on historical maps. In this context, Bonn and Poschlod (1998) stress the importance of land use and forest management activities, including forest grazing, as additional vectors for plant dispersal. They consider the long-distance dispersal that may result from these activities as an essential component in the population dynamics of woodland species.

This paper addresses the hypothesis that (former) human activities and rare events are significant in building up distribution patterns of (ancient) woodland plant species. We focus on an analysis of the genetic structure of the Wood sedge, Carex sylvatica Hudson, in its scattered distribution area in the Rhine floodplain in the Netherlands. Wood sedge is a well-known and easily recognised ancient woodland indicator (e.g., Wulf, 1997). Its occurrence in the study area (Mennema et al., 1985) has been known for a long time and is quite stable. However, the size of the populations, mostly situated in isolated woodlands, varies enormously: from single tussocks to populations covering a square kilometre. Moreover, although most populations are associated with old woodland, some are definitely not. These features make Carex sylvatica in this study area especially suited for addressing the above-mentioned hypothesis. We have used AFLP to study the genetic structure of populations because this technique enables the identification of genetically distinct individuals with just a few primer combinations (Arens et al., 1998; Escaravage et al., 1998). A number of (putative) co-dominant AFLP loci and one polymorphic microsatellite locus were also used to study the breeding system. 

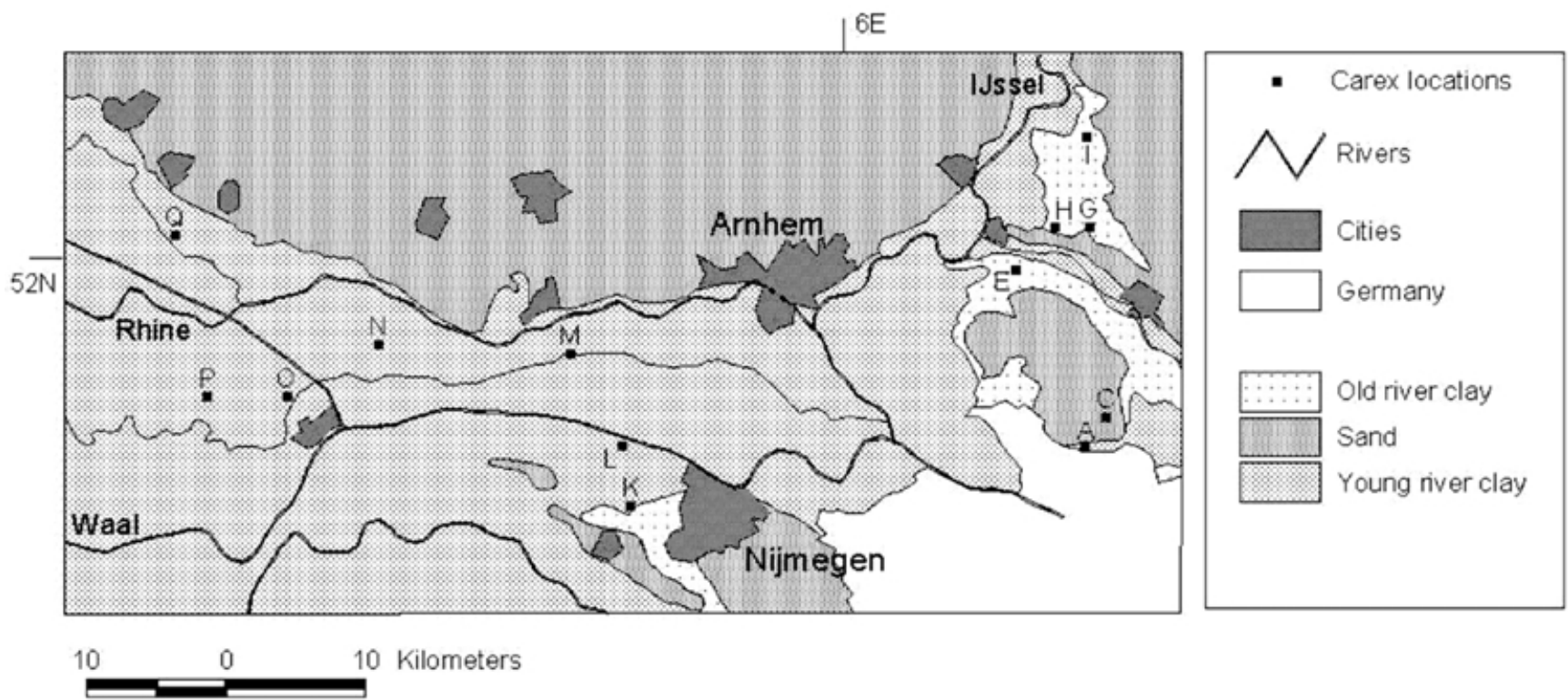

Fig. 1 Map of part of the Rhine flood plain in the centre of the Netherlands showing all sites with Wood sedge (see Table $\mathbf{1}$ for names).

\section{Materials and Methods}

\section{Description of species and study area}

Carex sylvatica is a perennial, caespitose species (without creeping rhizomes) that belongs to the subgenus Carex, characterised by unisexual spikes. Wind is the main pollinating agent (Jermy et al., 1982). Wood sedge typically occurs on heavy soils in old woodlands (e.g., former coppices) and often thrives along forest rides. Germination does not occur in the dark and requires a fluctuating temperature with a mean amplitude of at least $10^{\circ} \mathrm{C}$ (Schütz, 1999), reflecting the ability to regenerate quickly from the persistent seed bank (Hodgson et al., 1995) after soil disturbance, e.g., after coppicing or in canopy gaps.

The study area comprises the clay sediments associated with the river Rhine and its branches Waal and IJssel in the centre of the Netherlands (Fig. 1). Most localities on young clay of Holocene origin $(\mathrm{L}-\mathrm{Q})$ are situated in the Betuwe, the region between the rivers Rhine and Waal (Fig. $\mathbf{1}$ ), and are associated with old isolated park woodlands of estates or castles (L, M, O, and Q). Site $\mathrm{N}$ was laid out as an estate in the 19th century, with many exotic tree species. Soils are generally well-drained, sandy clays with a high calcium content (former river banks) supporting forests of oak and ash or poplar plantations. Site P is a former clay pit, now a nature reserve. The eastern localities (A, E, G, H, I, and K) occur on old clay of late Pleistocene origin. These clays have an acidified top layer. Forests on these soils were usually managed as coppice, which is the case for sites E, G, H, and K. For economical reasons, coppicing came to an end after World War I and coppice stands were turned into even-aged oak forests or became neglected. Site $C$ is an area of pine forest on sandy soil where logs of trees, imported from Germany, were processed in the early 20th century. Management history was evaluated by comparing woody species composition and forest structure with land use indicated on the first cadastral maps from 1832 and on earlier maps, if available. Features of sites are included in Table $\mathbf{1}$.

\section{Sampling and analysis strategy}

The occurrence of $C$. sylvatica plants in all sites where the species occurs south of the river Rhine was mapped in detail in spring 1998 and 1999. One site along the Old Rhine was included as well (Q). Most plants were found along paths, woodland rides, or logging tracks, usually in more or less clustered groups of tussocks (individuals). Clusters of tussocks will be denoted as patches. All 13 populations of Carex sylvatica in the central part of the Netherlands, representing a major part of the species distribution in the country, were sampled in spring 1998 or 1999 (Table $\mathbf{1}$ ).

A sample consisted of one young leaf from the interior of a tussock. For small patches (25 individuals or less), all tussocks were sampled, whereas for large patches tussocks were sampled along two transects, perpendicular to each other, at intervals of about $5 \mathrm{~m}$. Individuals were numbered and mapped per patch. Analysis of the field-collected samples was conducted in two rounds, to maximise the number of unique genotypes found while circumventing analysis of a series of identical genotypes. In the first round the number of different genotypes per patch was estimated in all patches for all sites, by analysing for each patch, depending on its size, 2 to 11 evenly distributed samples (see Fig. 2 for an example). For those patches that turned out to contain more than one genotype, more samples per patch were analysed in a second round. As a control, additional samples were also analysed from a number of patches with only identical samples in the first round. In none of those cases were additional genotypes found in the second round. For the populations in park woodlands, this sampling encompassed all plants present (except for a few plants which were lost during analysis). For the larger populations in coppice woods, notably populations $\mathrm{G}$ and $\mathrm{H}$, the two rounds of 
Table 1 Features of the studied sites (as indicated in Fig. 1) and a summary of the genetic diversity within sites; Area codes: 1 (< 10 ha), 2 (1025 ha), 3 ( $25-50$ ha), 4 (50-100 ha), and 5 (> 100 ha). Forest type codes: C: (former) coppice wood, P: park woodland, X: new establishments in forest with other management. Number of patches (NP), number of individuals or tussocks analysed ( $\mathrm{Nl}$; ${ }^{*}$ : all individuals sampled and analysed) and the number of phenotypes (NG) found in each site, as well as the average (across all NG), minimum and maximum similarity between phenotypes. $\mathrm{H}_{\mathrm{O}}$ and $\mathrm{H}_{\mathrm{E}}$ are the observed and expected heterozygosity in each population across all six co-dominantly scored loci. CL113 describes the distribution of alleles found with this SSR locus at each site

\begin{tabular}{|c|c|c|c|c|c|c|c|c|c|c|c|}
\hline \multicolumn{2}{|c|}{ Abbreviation and name of site } & \multirow[t]{2}{*}{ Area } & \multirow[t]{2}{*}{$\begin{array}{l}\text { Forest } \\
\text { type }\end{array}$} & \multirow[t]{2}{*}{ NP } & \multirow[t]{2}{*}{$\mathrm{NI}$} & \multirow[t]{2}{*}{ NG } & \multicolumn{2}{|c|}{$\begin{array}{l}\text { Genetic similarity } \\
\text { based on AFLP }\end{array}$} & \multicolumn{3}{|c|}{$\begin{array}{l}\text { Results from the co-domi- } \\
\text { nant loci }\end{array}$} \\
\hline & & & & & & & Mean & Min-max & $\mathrm{H}_{\mathrm{O}}$ & $\mathrm{H}_{\mathrm{E}}$ & $\begin{array}{l}\text { Alleles at } \\
\text { CL113" }\end{array}$ \\
\hline A & Bergh, De Plantage & 2 & $\mathrm{P}$ & 1 & $2^{\mathrm{A}}$ & 1 & & & 0 & 0 & $\mathrm{~B}$ \\
\hline C & Bergh, Bergherbos Zuid & 5 & $x$ & 1 & $4^{\mathrm{A}}$ & 2 & $0.96^{*}$ & & 0.16 & 0.09 & B \\
\hline $\mathrm{E}$ & Angerlo, Bevermeer & 2 & $\mathrm{C}$ & 8 & 49 & 4 & 0.68 & $0.63-0.98$ & 0 & 0.17 & B \\
\hline G & Hummelo, Enghuizen & 3 & $\mathrm{C}$ & 4 & 26 & 18 & 0.81 & $0.63-0.98$ & 0.05 & 0.32 & $B, D, E$ \\
\hline $\mathrm{H}$ & Hoog-Keppel, Ulenpas & 3 & $\mathrm{C}$ & 8 & 43 & 26 & 0.80 & $0.66-0.98$ & 0.08 & 0.28 & $A, B, E$ \\
\hline I & Baak, Hertenbos & 2 & $P$ & 2 & $3^{A}$ & 1 & & & 0 & 0 & B \\
\hline K & Beuningen, Personnenbos & 2 & C & 6 & 11 & 8 & 0.89 & $0.67-0.98$ & 0 & 0.16 & $\mathrm{~B}, \mathrm{C}$ \\
\hline $\mathrm{L}$ & Ewijk, Doddendaal & 1 & $P$ & 2 & $5^{\mathrm{A}}$ & 1 & & & 0 & 0 & B \\
\hline M & Hemmense bos & 2 & $P$ & 1 & 7 & 1 & & & 0 & 0 & B \\
\hline $\mathrm{N}$ & Ommeren, Den Eng & 2 & $P$ & 5 & $8^{A}$ & 3 & 0.96 & $0.95-0.98$ & 0 & 0.04 & B \\
\hline $\mathrm{O}$ & Zoelense bos & 3 & $P$ & 13 & 36 & 14 & 0.87 & $0.68-0.98$ & 0.01 & 0.09 & B \\
\hline$P$ & Buren, clay pit & 1 & $x$ & 1 & 14 & 1 & & & 0 & 0 & $E$ \\
\hline Q & Cothen, Hardenbroek & 2 & $\mathrm{P}$ & 1 & 8 & 6 & 0.94 & $0.90-0.96$ & 0.03 & 0.16 & B \\
\hline \multicolumn{2}{|c|}{ Total } & & & 53 & 216 & 86 & & & 0.03 & 0.36 & \\
\hline
\end{tabular}

* Result from a single comparison between two phenotypes. " Alleles at CL113: A 207 bp, B 215 bp, C 217 bp, D 219 bp, E 223 bp.

sample analysis still represented a subset of the total number of plants present and actual numbers of genotypes within patches may be higher. In total, 216 plants were analysed.

\section{DNA extraction and genotyping}

Young leaves were collected in $2 \mathrm{ml}$ Eppendorf tubes, frozen in liquid nitrogen and stored at $-80^{\circ} \mathrm{C}$. Prior to DNA extraction, leaf samples were lyophilised and ground with 5-7 glass pearls in a shaking mill (Retch, Germany). DNA was extracted according to Fulton et al. (1995). The AFLP method was performed essentially as described by Vos et al. (1995) with some minor modifications (Arens et al., 1998). Out of 60 EcoRI/MseI primer combinations tested on four samples, four suitable combinations were selected based on the amount of unambiguously scorable bands (Table $\mathbf{2}$ ). To test reproducibility and estimate error rates, three independent DNA extractions from leaf material of the same plant were processed as if they were independent samples (Arens et al., 1998). This test was done for three different plants. For all four primer combinations used, identical banding patterns were found for all DNA extractions per plant.

To obtain a better insight into the breeding system of $C$. sylvatica, an analysis of variation using co-dominant markers may provide valuable information. Although most AFLP markers are dominant, some bands can be scored co-dominantly (Van Eck et al., 1995; Piepho and Koch, 2000). We searched for possible allelic AFLP bands by looking at co-migrating bands for which at least one of the two bands was present in each sample (Van Eck et al., 1995). More importantly, such co-migrating bands were only selected when band intensities were lower in samples in which both bands were present (putative heterozygous state) compared to samples in which only one of the two bands was present (putative homozygous state). In this study, five putative co-dominant AFLP loci fulfilled these criteria. Besides the co-dominant AFLP loci, six microsatellite loci originally developed for Carex limosa (J. Ouborg, Radboud University, Nijmegen, The Netherlands, pers. comm.) were tested for their applicability in C. sylvatica. Amplification conditions for microsatellite analyses were: 1 cycle $3 \mathrm{~min} 94^{\circ} \mathrm{C}$, 33 cycles $\left(45 \mathrm{~s} 94^{\circ} \mathrm{C} ; 45 \mathrm{~s} 55^{\circ} \mathrm{C} ; 105 \mathrm{~s} 72^{\circ} \mathrm{C}\right)$, followed by $10 \mathrm{~min} 72^{\circ} \mathrm{C}$. After separation on $6 \%$ denaturing polyacrylamide gels (National diagnostics, USA), amplification products were visualised with silver staining according to the Silver Sequence DNA Sequencing System (Promega, USA). Three microsatellite loci gave a scorable product in C. sylvatica and were tested on all samples. However, only one locus (CL113) was polymorphic, showing a total of five alleles.

\section{Data analysis}

Only unambiguously scorable polymorphic AFLP bands were recorded. Presence (1) or absence (0) of each of the polymorphic bands was scored for all individuals. The effective number of bands was calculated using POPGENE 1.31 (Yeh and Boyle, 1999). Similarity for each pair of samples was calculated using the simple matching coefficient (Sokal and Sneath 1963). Samples with a similarity of 1.0 were considered as one genotype and only one individual of each genotype was used in the description of genetic similarities. 


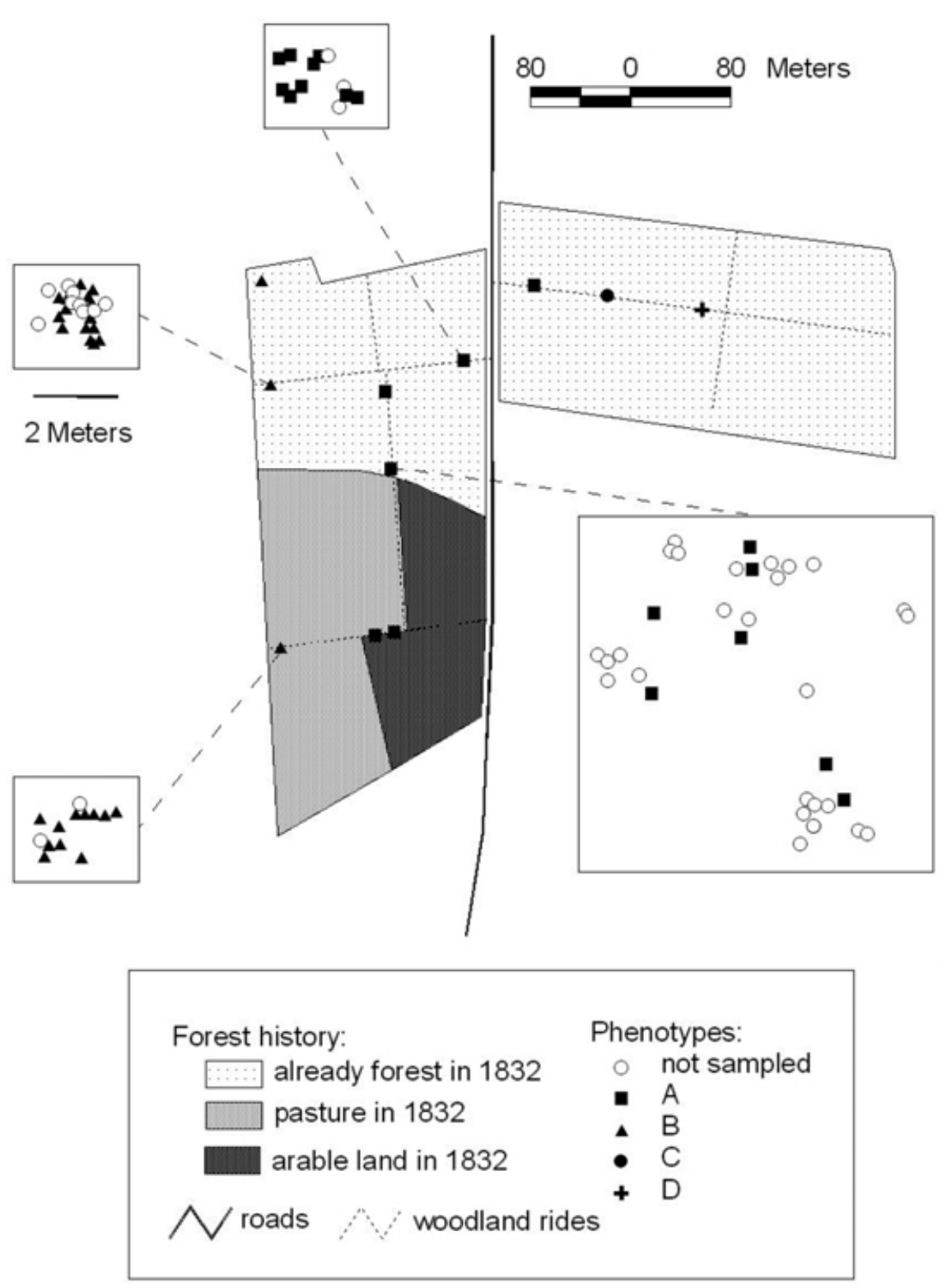

Fig. 2 Map of site E (Bevermeer) showing the spatial distribution of phenotypes. All individual plants are depicted. The four different symbols refer to the different phenotypes $(A-D)$ that were identified within this site (phenotype D has a similarity of $98 \%$ with phenotype A). For those patches in which clusters of plants were found, an enlargement of the spatial distribution is given in the rectangular boxes; the scale in these enlargements is indicated as a $2 \mathrm{~m}$ bar. Within these patches, all analysed plants have an identical phenotype and subsequently the phenotype symbol is used to position these clusters on the map. All other patches depicted contain only one plant. Different shadings refer to differences in age of the present woodland ("forest 2000") based on the land-use situation on a map from 1832 .

The bulk of the genetic data consisted of dominant AFLP markers, and these were used to infer the population genetic structure of $C$. sylvatica. Because it was clear from variation at the microsatellite locus and the putative co-dominant AFLP loci that the assumption of Hardy-Weinberg equilibrium for our populations was not justified, a phenetic approach was used to assess the population genetic structure from the AFLP data. For this, a principal co-ordinate analysis (PCO) was carried out based on the similarity matrix of all unique genotypes (Genstat 5; Payne et al., 1993). The variation within and between populations was partitioned using AMOVA 1.55 (Excoffier, 1995). Similarly, AMOVA was used to test significance of grouping in regions/river systems ( $\mathrm{A}-\mathrm{I}$ vs. $\mathrm{K}-\mathrm{Q}$ ) and between management types (Table $\mathbf{1}$ ). Significance values were assigned to variance components on the basis of a set of null distributions generated by 1000 permutations. Differences between management types (coppice or estate) on the number of genotypes per population were tested with one-way analyses of variance.

The correlation between genetic distance and geographical distance was tested using a randomisation test (Mantel, 1967). This Mantel randomisation test was used because genetic distances are calculated pairwise and are, thus, not independent. The Mantel test for correlation is equivalent to a randomisation test based on the t-statistic for testing whether the regression coefficient for genetic distance, of the regression of genetic distance on geographical distance, is significantly different from zero (Manly, 1997).

Genotypic data for the microsatellite CL113 and the co-dominant AFLP loci were used to examine the breeding system of C. sylvatica. No linkage disequilibria were found between the six loci when tested using POPGENE 1.31 (Yeh and Boyle, 
Table 2 Primer combinations used for AFLP profiling of C. sylvatica DNA, and the number of bands scored for each combination

\begin{tabular}{|c|c|c|c|c|c|}
\hline & \multicolumn{4}{|c|}{ Primer combination } & \multirow[t]{2}{*}{ Total } \\
\hline & 1 & 2 & 3 & 4 & \\
\hline \multicolumn{6}{|l|}{ Restriction enzyme } \\
\hline - Eco RI & AAG & AAG & ACA & ATC & \\
\hline - Mse la & AGC & ATC & ACT & AGG & \\
\hline No. of polymorphic bands & 14 & 17 & 16 & 10 & 57 \\
\hline Total no. of bands & 40 & 54 & 46 & 26 & 166 \\
\hline$\%$ polymorphic bands & 35 & 31 & 35 & 38 & 34 \\
\hline
\end{tabular}

a See Vos et al. (1995); only the three selective nucleotides are shown.

1999). The observed heterozygosity levels, inbreeding coefficient $\mathrm{F}_{\mathrm{IS}}$ and population differentiation $\mathrm{F}_{\mathrm{ST}}$ at these loci were calculated using TFPGA 1.3 (Miller, 1997).

\section{Results}

\section{AFLP analysis}

The four primer combinations used generated 166 scorable bands, of which 57 (34\%) were polymorphic, evenly distributed across the four primer pairs (Table 2 ). Thirteen bands were found to be unique to specific populations. The analogue of the effective number of alleles, the effective number of bands, was on average 1.4. Based on multi-locus banding patterns, a total of 86 phenotypes were identified within the 216 samples analysed (Table $\mathbf{1}$ ). The similarity between pairs of unique phenotypes across all woodlots ranged from 0.45 to 0.98 , with a mean of $0.73 \pm 0.08$ (S.D., $n=3655$ ).

\section{Genetic structure of populations}

Overall, only $40 \%$ of the analysed plants represented unique phenotypes (Table 1). Each phenotype was restricted to a particular population and not found in other populations. For five populations (I, A, P, L, and M), all samples within a population consisted of only a single phenotype (Table 1). Also, within each of the other populations, plants with identical phenotypes were found, both within and between patches, with distances between such patches of sometimes $1000 \mathrm{~m}$. Similarities between phenotypes below 0.9 were only present in five populations. Within the most intensively studied population E (Bevermeer near Angerlo), the 49 sampled tussocks represented only three clearly distinguishable phenotypes (Fig. 2, phenotypes A, B, and C; phenotype D is $98 \%$ identical to A). Two of these phenotypes ( $A$ and $B$ ) were found in a number of different patches each along two paths in the western (left) part of the woodland, with phenotype A extending into the eastern part. Here, a third phenotype $(C)$ was found as a single tussock. Probably these and possibly other phenotypes now no longer present had a more extensive distribution since the present woodland at site $\mathrm{E}$ is a remnant of a much larger complex of coppice woods that existed there at least up to 1920. A similar distribution pattern for phenotypes was found in population $\mathrm{K}$ (not shown): a number of distinct phenotypes throughout the woodland and plants within patches showing an identical phenotype, although here plants with an identical phenotype were only found within patches.
A much more diffuse pattern of phenotypes was recorded in the populations $\mathrm{O}$ (Fig. 3) and $\mathrm{G} / \mathrm{H}$, where phenotypes were less abundant and sometimes scattered throughout the woodland. The Zoelen estate (population 0 ) dates at least from the 13th century. A classical or French landscape style was laid out around 1670 . Interestingly, all phenotypes at this site were present in a part of the park wood that contained a star of avenues ("sterrebos"), a typical component of the French landscape style that was felled in 1828 and which became part of the more fashionable English landscape style. Ten phenotypes, out of the total of fourteen, were unique to this "sterrebos". In contrast, the oldest and less disturbed wooded part of the park (southern, triangular shaped parcel in Fig. 3) contained only one single tussock of phenotype A. In the northern, youngest (post 1800) part of the park wood two phenotypes were present ( $A$ and $B)$.

A principal co-ordinate analysis (PCO, Fig. 4) revealed three marginally differentiated groups; i) all but one of the phenotypes from $\mathrm{K}$, ii) all but two phenotypes from $\mathrm{G}$, one from $\mathrm{H}$, and a small "phenotype group" from $\mathrm{E}$, and iii) all other phenotypes. The PCO plot does not show a clear separation of phenotypes according to geographic origin.

AMOVA analysis revealed that variation within populations comprised $55 \%$ of the total variation, indicating an almost equal contribution of within- and between-population genetic variation to the total genetic diversity (Table 3 ) even though five locations did not contribute to the within-population variation at all. Variation between regions/river systems accounted for only $3.8 \%$ of overall genetic variation, and was not significant $(p=0.15)$. Similarly, individuals between management types (coppice versus park woodland; Table 1) showed no significant genetic differentiation ( $p=0.17)$. However, the number of phenotypes per population was significantly higher (oneway ANOVA, $p=0.05$ ) in the coppice woodlands despite the almost complete sampling of individuals in the park woodlands. A Mantel test, performed on the pairwise population genetic and geographic distances could not detect an isolation-by-distance relationship between populations. However, significant variation could occur over short distances, for example AMOVA showed that the two adjacent populations $\mathrm{G}$ and $\mathrm{H}$ (on estates, H: Ulenpas and Hekenbroek; G: Enghuizen), which were separated by a road, were significantly different from each other $(p<0.001)$. Nevertheless, one phenotype was found in both populations (one plant each), $1000 \mathrm{~m}$ apart. Furthermore, the PCO showed two phenotypes from population $G$ that clustered with samples from population $\mathrm{H}$. 


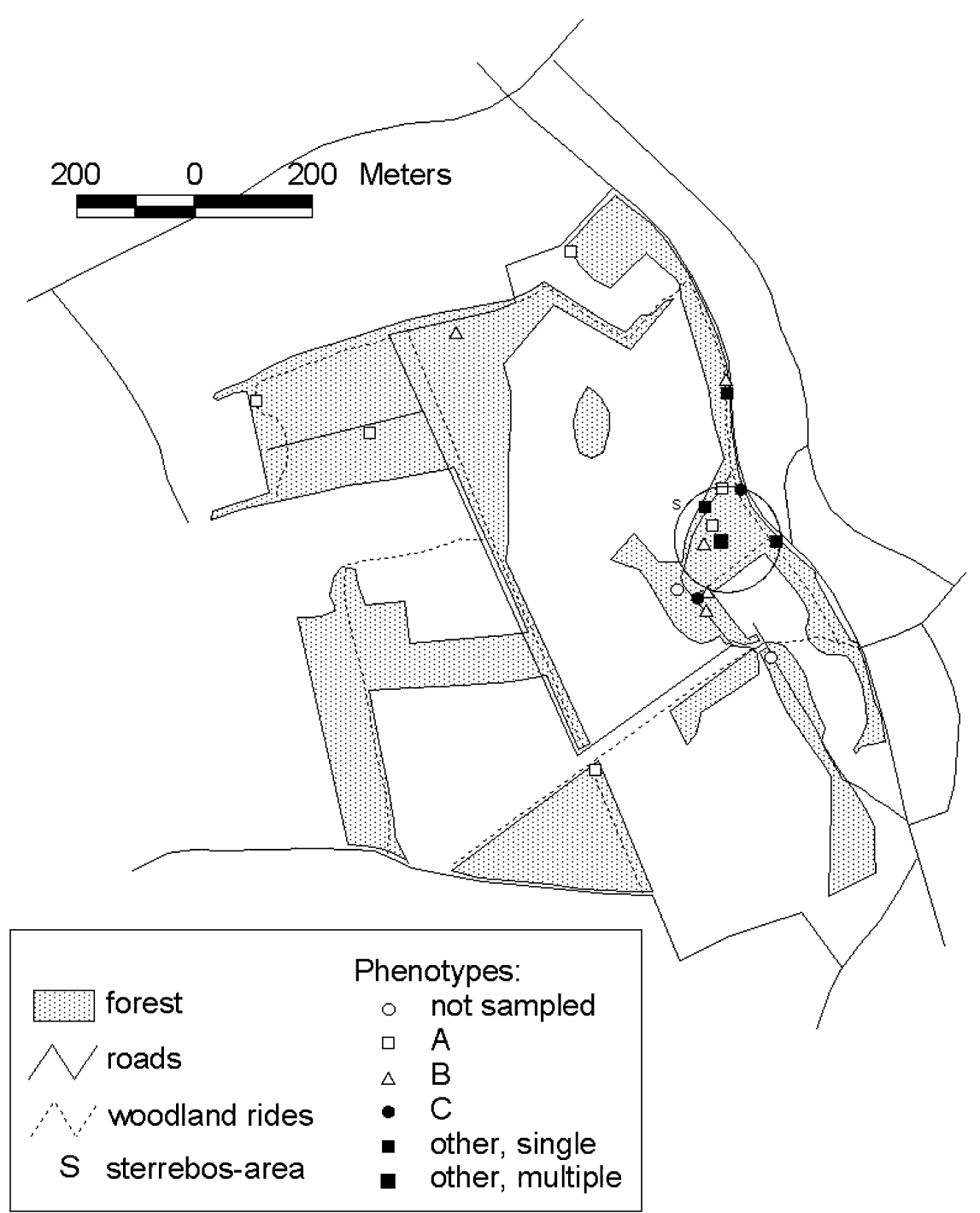

Fig. 3 Map of site O (Zoelen Estate) showing the spatial distribution of phenotypes. The large solid square consists of 8 unique phenotypes occurring in the former "sterrebos" (unpaved avenues radiating outwards in a star shape), in which the intensity of woodland management was relatively high.

\section{Local distribution, heterozygosity level, and breeding system}

Detailed maps drawn for a number of patches (data not shown) indicated that tussocks increase in diameter every year (by new shoots) and also that patches increase in size by the establishment of new plants at the periphery of a patch. For patches in site E, the average distance between a plant and its nearest neighbour was $33 \mathrm{~cm}($ S.D. $=24, \mathrm{n}=82)$. All measured distances between plants, including young plants established at the periphery of a patch, clearly exceed the estimated maximal annual rhizomal growth of $5 \mathrm{~cm}$ (Brunet and von Oheimb, 1998). Excavation of root systems of neighbouring plants in population P indicated establishment from seeds, even though these plants had identical banding patterns.

In addition to identical phenotypes and clearly distinctive phenotypes, a number of "phenotype groups" could be discerned consisting of 2 to 9 plants with similarities between 0.9 and 1.0. Plants belonging to such a "phenotype group" were always found within the same population. In three sites $(\mathrm{C}, \mathrm{N}$, and Q) such a "phenotype group" encompassed all extant plants.
All other populations with multiple phenotypes (E, G, H, K, and $\mathrm{O}$ ) also contained such "phenotype groups".

Over the five co-dominant AFLP loci, 21 heterozygous plants were found of which 17 plants were heterozygous at one locus only. At the microsatellite locus CL113 7 heterozygote plants were detected, which was comparable to the number of heterozygotes found at each co-dominant AFLP locus (Table 4). Four of the heterozygote scores at the microsatellite locus were found in plants that were also heterozygous at two or three of the co-dominant AFLP loci. In total, 24 plants were found heterozygous at 36 locus * plant combinations at the six co-dominant loci combined. Some of the heterozygous plants occurred in populations $\mathrm{C}$ and $\mathrm{Q}$, where all plants within the population belonged to the same "phenotype group". All other heterozygous plants were present in populations $\mathrm{G}, \mathrm{H}$, and $\mathrm{O}$, in which different phenotypes grew in close proximity. Five of these plants were heterozygous at 2 to 4 loci, of which four plants were from the same "phenotype group" in population $\mathrm{H}$. Interestingly, three of these plants have identical banding patterns and are considered to be one phenotype but 


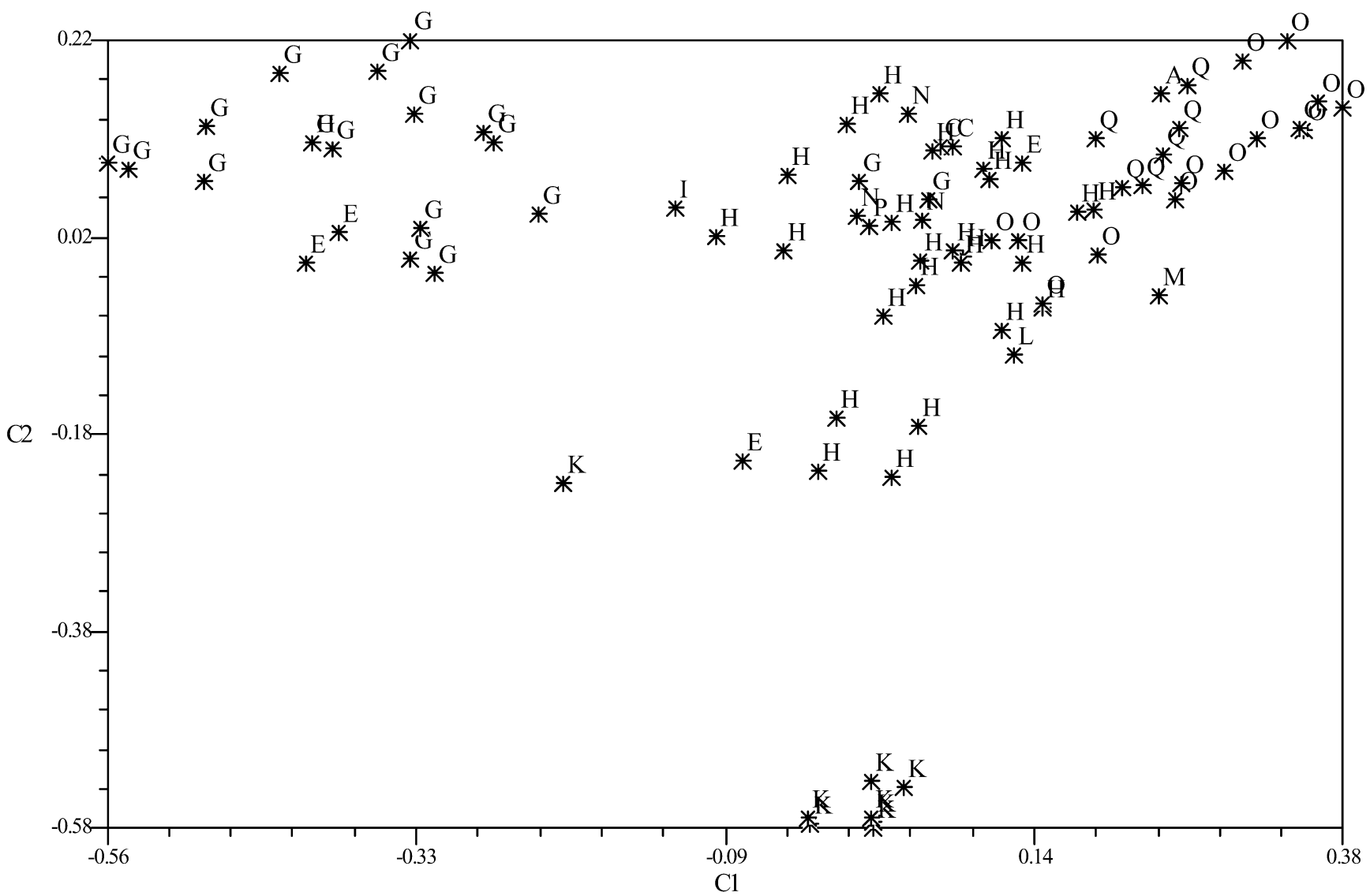

Fig. 4 Principal co-ordinate analysis of the AFLP profiles. The percentage of variation accounted for by the first two axes was 20.1 and 13.6, respectively. Letters indicate origin of genotype, see Table 2 for the coding of woodlots. occurred $10 \mathrm{~m}$ apart. Every heterozygous plant detected in this study belonged to a "phenotype group".

Across all six co-dominant loci, inbreeding was estimated to be very high $\left(F_{I S}=0.84,95 \%\right.$ confidence interval $0.78-0.89$ ). Accordingly, the observed heterozygosity was very low $\left(\mathrm{H}_{\mathrm{O}}=\right.$ 0.029, Table 4) compared to the expected heterozygote frequency with random mating $\left(\mathrm{H}_{\mathrm{E}}=0.36\right.$, Table 4).

\section{Discussion}

\section{AFLP analysis}

The total number of scorable bands and hence the number of polymorphic bands was relatively low. For example, in black poplar (Populus nigra) the average number of polymorphic bands per primer combination was 53 (Arens et al., 1998) compared to only 14 in Carex sylvatica. The low number of bands may reflect the relatively small genome sizes (2C around $2 \mathrm{pg}$ DNA) within the genus Carex (Bennett et al., 1998), since a high percentage (34\%) of the scorable bands were polymorphic. Four primer combinations generated in total 57 polymorphic loci, which was sufficient to distinguish phenotypes. Considering the effective number of bands, $(1.4)^{57}=2.13 \times 10^{8}$ different phenotypes can theoretically be distinguished from the AFLP analysis.

\section{Mode of reproduction}

In concordance with the view of Ford et al. (1991) that caespitose Carex species are inbreeding, the heterozygosity levels indicate that $C$. sylvatica is a highly selfing species. In contrast to other caespitose species, $C$. sylvatica does not have multiple bisexual spikes or close proximity of male and female spikelets. However, we did observe a considerable overlap in flowering time of male and female flowers. Furthermore, when flowering starts culms are still very short $(15 \mathrm{~cm})$ and packed closely together, more or less hidden by old leaves. Only after pollination, at the onset of seed development, do culms grow to their full length $(0.6-1 \mathrm{~m})$. We found circumstantial evidence for the effect of flowering conditions on outbreeding rate in $C$. remota (P. Arens and R-J Bijlsma, unpublished). In this species, flowering starts much later when culms are already grown to their full size. Heterozygosity levels in all C. remota plants $(\mathrm{n}=79$ ) found in the same 13 sites were four times higher than in $C$. sylvatica $\left(\mathrm{H}_{\mathrm{O}}=0.12\right.$ vs. 0.029$)$, even though populations were much smaller and expected heterozygosity levels were comparable $\left(\mathrm{H}_{\mathrm{E}}=0.32\right.$ for $C$. remota and 0.36 for $C$. sylvatica $)$.

The genetic variation within and between populations of caespitose Carex species has been assessed in a number of studies using allozymes (Bruederle and Jensen, 1991; Waterway, 1990; Ford et al., 1998). All three studies found similar or lower percentages of unique phenotypes compared to our study. The 
Table 3 Nested Analysis of Molecular Variance (AMOVA) for 86 phenotypes from two regions/river systems and 13 populations. Statistics include sums of squared deviations (SSDs), mean squared deviations (MSDs), variance component estimates, the percentage of the total variance contributed by each component (\%), and the probability (P) of obtaining a more extreme component estimate by chance alone (using 1000 randomisations)

\begin{tabular}{lrrrrrr}
\hline Source of variation & df & SSD & MSD & Variance & $\%$ & $p$ value \\
& & & & component & \\
\hline Among regions & 1 & 64.34 & 64.34 & 0.3 & 3.76 & 0.146 \\
Among populations/within regions & 11 & 252.63 & 22.97 & 3.5 & 41.1 & $<0.001$ \\
Among individuals/within populations & 73 & 342.96 & 4.70 & 4.7 & 55.1 & $<0.001$ \\
\hline
\end{tabular}

Table 4 Heterozygosity levels of co-dominantly scorable AFLP bands and microsatellite locus CL113

\begin{tabular}{llll}
\hline Locus & Sample size & $\mathrm{H}_{\mathrm{O}}$ & $\mathrm{H}_{\mathrm{E}}$ \\
\hline ACA/ACT-3.5/3.7 & 215 & 0.0048 & 0.1696 \\
ATC/AGG-3/4 & 216 & 0.0333 & 0.3986 \\
ATC/AGG-5/6 & 216 & 0.0381 & 0.4248 \\
AAG/AGC-3/4 & 216 & 0.0238 & 0.4993 \\
AAG/ATC-6/7 & 213 & 0.0338 & 0.4591 \\
CL113 & 216 & 0.0381 & 0.2290 \\
Mean & 215 & 0.0287 & 0.3634 \\
S.D. & & 0.0128 & 0.1328 \\
\hline
\end{tabular}

first two studies showed the generally expected pattern for selfing plants, with relatively little genetic variation found within populations. The study of Ford et al. (1998), however, showed that members of the $C$. willdenowii complex do not fit this classificatory framework. These sedges all showed higher than expected heterozygosity values, which are thought to result from selection or dis-assortative mating combined with vegetative spread of the heterozygous plants. With $55 \%$ of the genetic variation found within populations, the isolated C. sylvatica populations in our study show a slightly intermediate position within the caespitose sedges. With its high selfing rate and plant longevity, $C$. sylvatica can maintain genetic variation between phenotypes within populations for a considerable time.

The high numbers of identical phenotypes found in all populations could be the result of either vegetative propagation, dispersal of vegetative plant parts, or even seed dispersal (see below). Caespitose sedges like $C$. sylvatica lack creeping rhizomes, and although each year young shoots develop such that tussock slowly increases in diameter, rhizome growth has been estimated at less than $5 \mathrm{~cm}$ per year (Brunet and von Oheimb, 1998). Dispersal of vegetative plant parts is more likely to occur. Ford et al. (1998) considered natural disturbance leading to dispersal of vegetative plant material combined with balancing selection as the most probable cause for the heterozygote excess they found. We found some evidence for vegetative dispersal in population $\mathrm{H}$ because two identical heterozygous plants were found $10 \mathrm{~m}$ apart. Nevertheless, the strong rooting system of the Carex sylvatica plants and the heavy clay they grow upon makes frequent unintentional transport of vegetative plant material over distances of tens to hundreds of metres unlikely, even in the case of severe soil disturbance, such as in logging tracks.

Like in many highly selfing plant species, identical phenotypes can also arise from seed dispersal. Offspring from a repeatedly selfed, homozygous plant will have identical banding patterns even though they are derived through generative propagation. Indeed, young plants at the periphery of mapped patches, 15 to $60 \mathrm{~cm}$ away from possible parent plants but clearly derived from seed, were found to be genetically identical to the other plants in that patch. An estimate of the migration rate could be made in population $P$ that established itself in an old clay pit (on former grassland) that was abandoned in 1960. This population consists of just one phenotype that succeeded in forming a dense population extending over an area of about $30 \times 5 \mathrm{~m}$ in only 40 years. This corresponds to a (two-sided) expansion rate of around $37.5 \mathrm{~cm} /$ year. The average distance between neighbouring plants, measured in a number of patches, and the estimated migration rate from population $\mathrm{P}$ are comparable to the annual migration rate of $48 \mathrm{~cm}$ found by Brunet and von Oheimb (1998). These distances correspond to the distances where culms (15-100 cm; Sebald, 1998) can be expected to shed seeds when they bow down or fall on the ground. However, identical plants were also found in patches 20 $1000 \mathrm{~m}$ from each other in all sites with two or more patches, indicating seed dispersal over considerable distances.

\section{Genetic structure at the regional and local scale}

It is clear that we do not fully understand the historical and current population dynamics of $C$. sylvatica yet. In the studied region, $C$. sylvatica is at the margin of its species range (Sebald, 1998). We hypothesise that the high genetic diversity of $C$. sylvatica in woodlands is the result of the accumulation of a number of independent establishments. The most important vector for long-range dispersal has probably been the River Rhine bringing down seeds from large upstream populations in Germany, where the species is much more abundant. Seeds are capable of floating for several months (Ridley, 1930) and viable seeds of $C$. sylvatica have been found in sediments of a flood disaster (Schwabe, 1991). Although a regular phenomenon up to about 1850 (e.g., in 1740 the whole Betuwe area was severely flooded), major flooding has been successfully prevented since then (Van de Ven, 1993). The lack of a correlation between genetic and geographic distances between the populations, and the absence of $C$. sylvatica from several other equally suitable park woodlands in the study area, are consistent with this putative dispersal mechanism. The recent appearance of 
C. sylvatica in the atypical locations $\mathrm{C}$ and $\mathrm{P}$ cannot easily be explained and might have an anthropogenic cause.

Within populations it is clear that most seeds disperse for very small distances that are consistent with ant dispersal or simply shedding from the plants. Nevertheless, individual phenotypes of $C$. sylvatica within populations are also distributed over relatively large distances of up to $1000 \mathrm{~m}$. Local management activities, whereby soil and litter, including persistent seeds, is transported at a local scale, or epizoochoric and anthropogenic dispersal (seeds have a long beak and may adhere to cloths and fur) may play an important role in creating these patterns.

The effects of local management activities on the genetic variation within sites warrants further research. The (former) coppice woods E, G, H, and $\mathrm{K}$ show significantly more phenotypes than the extensively managed park woodlands. In the park woodland $\mathrm{O}$ (Zoelen estate), an exceptionally high concentration of phenotypes (13 out of 14 in total) occurs in the former "sterrebos" (Fig. 3) that was subjected to severe disturbances before it reached its present form as high forest. In both sites $\mathrm{E}$ (Fig. 2) and O (Fig. 3) the occurrence of C. sylvatica is mainly associated with woodland rides and avenues, suggesting that the principal dispersal vectors use this infrastructure.

An alternative reason why $C$. sylvatica occurs mainly along rides might be that the woodland interior of most former coppice woods becomes more and more hostile (too dark, too much litter accumulation) not only for establishment but also for survival of Wood sedge. Coppicing ceased around 1920 and the resulting change in disturbance regime may have negatively affected both the dispersal of seeds and the availability of suitable habitat for recruitment. Barkham's (1992) study of the relationship between plant species diversity and intensity of disturbances relevant to woodland management shows that species which benefit most from coppicing lack the ability for rhizomatous clonal growth as well as the production of superabundant seeds.

In conclusion, within this study, observations on recent establishments and the results of the distribution of genetic diversity do implicate the involvement of other mechanisms in dispersal apart from ants (e.g., Hermy et al., 1999). Further research on the effects of human land use and forest management activities, such as coppicing, on the spatial distribution of genotypes and the genetic diversity within populations of C. sylvatica is warranted, as is probably the case for many other plant species in old forests.

\section{Acknowledgements}

We thank the nature conservation organisations Staatsbosbeheer (Zoelen, Doddendaal, Personnenbos), Natuurmonumenten (Hekenbroek, Bevermeer, Bergherbos) and Geldersch Landschap (Den Eng) for their permission for and their co-operation with the fieldwork. We also thank Joop Ouborg for the gift of the Carex limosa microsatellite primers and Paul Keizer for writing a Genstat application. Wilke van Delden and two anonymous reviewers are kindly acknowledged for their valuable comments on the manuscript. This study was partly funded by DLO and by the Biodiversity programme (383) of the Ministry of Agriculture, Nature and Food Quality.

\section{References}

Arens, P., Coops, H., Jansen, J., and Vosman, B. (1998) Molecular genetic analysis of Black poplar (Populus nigra L.) along Dutch rivers. Molecular Ecology 7,11-18.

Barkham, J. P. (1992) The effects of coppicing and neglect on the performance of the perennial ground flora. In Ecology and Management of Coppice Woodlands (Buckley, G. P., ed.), London: Chapman and Hall, pp.115-146.

Bennett, M. D., Cox, A. V., and Leitch, I. J. (1998). Angiosperm DNA Cvalues database. http://www.rbgkew.org.uk/cval/database1.html.

Bonn, S. and Poschlod, P. (1998) Ausbreitungsbiologie der Pflanzen Mitteleuropas. Wiesbaden: Quelle and Meyer.

Bruederle, L. P. and Jensen, U. (1991) Genetic differentiation of Carex flava and Carex viridula in West Europe (Cyperaceae). Systematic Botany 16, 41- 49 .

Brunet, J. and Von Oheimb, G. (1998). Migration of vascular plants to secondary woodlands in southern Sweden. Journal of Ecology 86, $429-438$

Escaravage, N., Questiau, S., Pornon, A., Doche, B., and Taberlet, P. (1998) Clonal diversity in a Rhododendron ferrugineum $\mathrm{L}$. (Ericaceae) population inferred from AFLP markers. Molecular Ecology 7, 975-982.

Excoffier, L., Smouse, P. E., and Quattro, J. M. (1995). Analysis of molecular variance inferred from metric distances among DNA haplotypes: application to human mitochondrial DNA restriction data. Genetics 131, 479-491.

Ford, B. A., Ball, P. W., and Ritland, K. (1991) Allozyme diversity and genetic relationships among North American members of the short-beaked taxa of Carex (Cyperaceae). Systematic Botany 16, $116-131$.

Ford, B. A., McQueen, D. A. R., Naczi, R. F. C., and Reznicek, A. A. (1998) Allozyme variation and genetic relationships among species in the Carex willdenowii complex (Cyperaceae). American Journal of Botany $85,546-552$.

Fulton, T. M., Chunwongse, J., and Tanksley, S. D. (1995) Microprep protocol for extraction of DNA from tomato and other herbaceous plants. Plant Molecular Biology Reporter 13, 207-209.

Hermy, M., Honnay, O., Firbank, L., Grashof-Bokdam, C., and Lawesson, J. E. (1999) An ecological comparison between ancient and other forest plant species of Europe, and the implications for forest conservation. Biological Conservation 91, 9-22.

Hodgson, J. G., Grime, J. P., Hunt, R., and Thompson, K. (1995) The Electronic Comparative Plant Ecology. London: Chapman and Hall.

Jermy, A. C., Chater, A. O., and David, R. W. (1982) Sedges of the British Isles. BSBI Handbook No 1. London: BSBI.

Mantel, N. (1967) The detection of disease clustering and a generalized regression approach. Cancer Research 27, 209-220.

Manly, B. F. J. (1997) Randomization, Bootstrap and Monte Carlo Methods in Biology, 2nd edition. New York: Chapman and Hall.

Mennema, J., Quenéne-Boterenbrood, A. J., and Plate, C. L. (1985) Atlas van de Nederlandse Flora 2. Zeldzame en Vrij Zeldzame Planten. Utrecht: Bohn, Scheltema and Holkema.

Miller, M. P. (1997) Tools For Population Genetic Analyses 3.1 (TFPGA). A windows program for the analysis of allozyme and molecular population genetic data. http://bioweb.usu.edu/mpmbio/ index.htm.

Nordén, B. and Appelqvist, T. (2001). Conceptual problems of ecological continuity and its bioindicators. Biodiversity and Conservation 10, 779-791.

Payne, R. W., Lane, P. W., Digby, P. G. N. et al. (1993). Genstat 5 Reference Manual, Release 3. Oxford: Oxford University Press.

Peterken, G. F. (1994) The definition, evaluation and management of ancient woods in Great Britain. NNA-Berichte 7,102-114.

Piepho, H. P. and Koch, G. (2000) Codominant analysis of banding data from a dominant marker system by normal mixtures. Genetics $155,1459-1468$. 
Rackham, O. (1976) Trees and Woodland in the British Landscape. London: Dent.

Rackham, O. (1980) Ancient Woodland, its History, Vegetation and Uses in England. London: Arnold.

Ridley, H. N. (1930) The Dispersal of Plants throughout the World. Ashford: L. Reeve and Co.

Schütz, W (1999) Germination responses of temperate Carex-species to diurnally fluctuating temperatures - a comparative study. Flora $194,21-32$.

Schwabe, A. (1991) Zur Wiederbesiedlung von Auenwald-Vegetationskomplexen nach Hochwasser-Ereignissen: Bedeutung der Diasporen-Verdriftung, der generativen und vegetativen Etablierung. Phytocoenologia 20, 65-94.

Sebald, O, (1998) Carex L. In Die Farn- und Blütenpflanzen BadenWürttembergs, Bd. 8 (Sebald, O. et al., ed.), Stuttgart: Eugen Ulmer, pp. $98-248$.

Sokal, R. R. and Sneath, P. H. A. (1963). Principles of Numerical Taxonomy. San Francisco: Freeman, pp. 359.

Van de Ven, G. P. (1993). Man-Made Lowlands: History of Water Management and Land Reclamation in the Netherlands. Utrecht: Matrijs.

Van Eck, H. J., Van der Voort, J. R., Draaistra, J. et al. (1995) The inheritance and chromosomal localisation of AFLP markers in a non-inbred potato offspring. Molecular Breeding 1, 397-410.

Vos, P., Hogers, R., Bleeker, M. et al. (1995) AFLP: a new technique for DNA fingerprinting. Nucleic Acids Research 23, 4407-4414.

Waterway, M. J. (1990) Genetic differentiation and hybridization between Carex gynodynama and Carex mendocinensis (Cyperaceae) in California (USA). American Journal of Botany 77, 826-838.

Wulf, M. (1997) Plant species as indicators of ancient woodland in northwestern Germany. Journal of Vegetation Science 8, 635-642.

Yeh, F. C. and Boyle, T. (1999) POPGENE VERSION 1.31 Microsoft Window-based freeware for population genetic analysis. http://www. ualberta.ca/ fyeh/info.htm.

\section{P. Arens}

Department of Biodiversity and Breeding

Plant Research International

Wageningen UR

P.O. Box 16

6700 AA Wageningen

Netherlands

E-mail: paul.arens@wur.nl

Editor: F. R. Scarano 